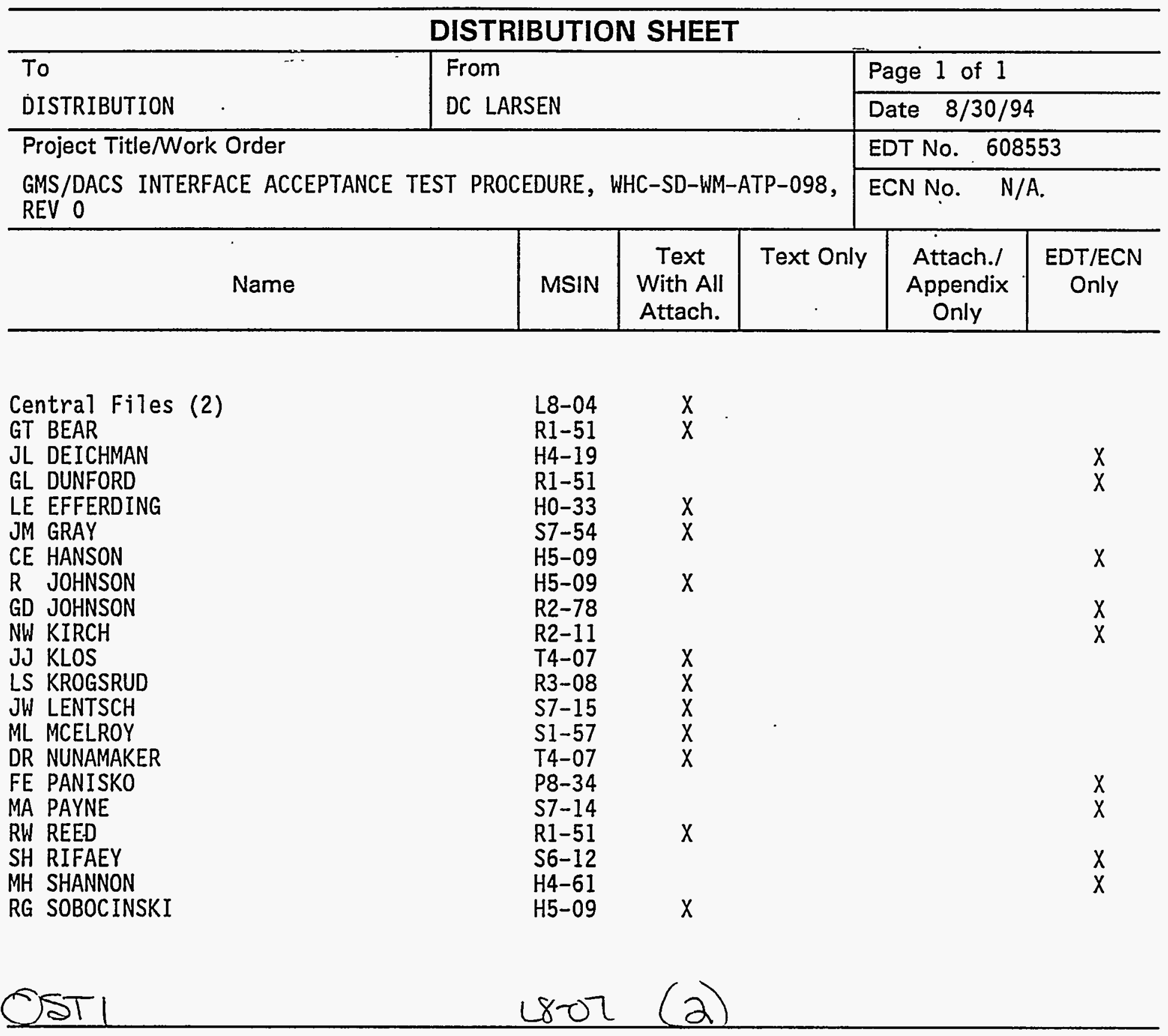




\section{DISCLAIMER}

Portions of this document may be illegible in electronic image products. Images are produced from the best available original document. 
2. To: (Receiving Organization) DISTRIBUTION

5. Proj./Prog./Dept./Div.: HMT
3. From: (Originating Organization)
TEST ENGINEERING

6. Cog. Engr.:

DC LARSEN

\section{Originator Remarks:}

Procedure will perform acceptance testing for new gas monitoring equipment and related software, after installation in the DACS trailer.
4. Related EDT NO.:

$N / A$

7. Purchase order No.:

$N / A$

9. Equip./Component No.:

$N / A$

10. System/Bldg./Facility:

$N / A$

11. Receiver Remarks:

$N / A$

12. Major Assm. Dwg. No.:

$N / A$
13. Permit/Permit Application No.: $N / A$

14. Required Response Date: $N / A$

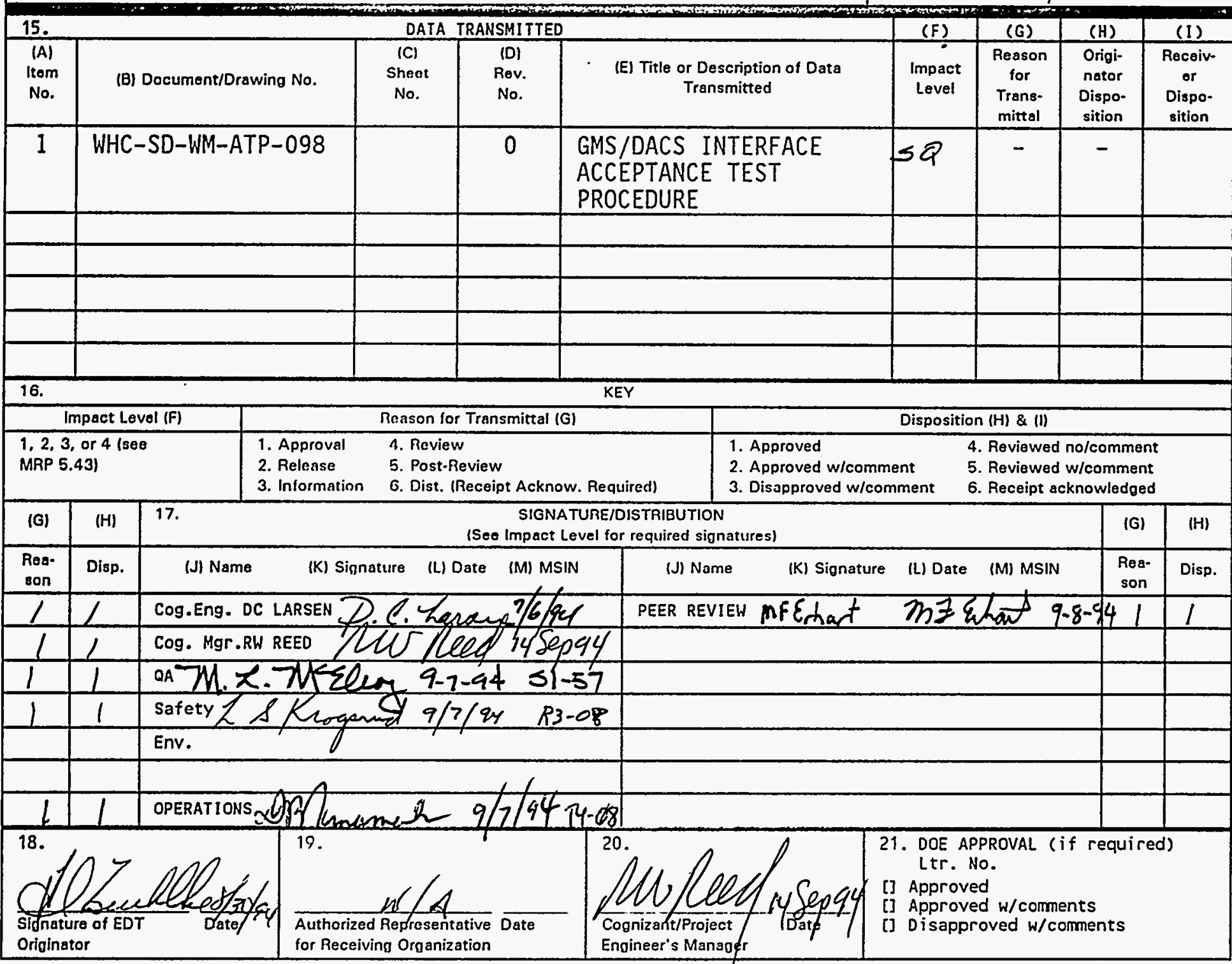




$$
\text { EDT-608553 Paqe } 2 \text { of } 2
$$

WASTE TANKS ADMINISTRATION

UNREVIEWED SAFETY QUESTIONS
Manual

Section

Page

Effective Date
WHC-IP-0842

15.9, REV 1

15 of 25

September 3, 1993

\section{APPENDIX B}

Unreviewed Safety Question Forms

Figure B-1. Unreviewed Safety Question - Changes Screening Form. (1 Sheet)

REFERENCE ITEM \# WHC-SD-WM-ATP-098 REV 0

TITLE GMS/DACS INTERFACE ACCEPTANCE TEST PROCEDURE

Does the referenced item:

A. Make PROPOSED CHANGES to the facility or procedures which differ from conditions described in the AUTHORIZATION BASIS documentation?
N/A
NO $X$
Yes/Maybe

Basis: The above mentioned reference item was evaluated for its impact on of the Safety Assessment for Proposed Pump Operation to Mitigate Episodic Gas Releases in Tank 241-SY-101 LAUR-92-3196 REV 11, in particular chapters 3 (Identification of Hazards), 6 (Controls for Mixer Pump Operations). Based on the evaluation. WHC-SD-ATP-098 REV 0 does not make proposed changes which differ from this safety assessment. The Above referenced item tests the alarm and abort limits.

B. Make PROPOSED CHANGES that represent conditions that have not been analyzed in the AUTHORIZATION BASIS?
$N / A$
NO $X$
Yes/Maybe

Basis: The authorization basis establishes boundaries for safe operation of the pump in regards to tank gas concentrations. The changes ensures that the appropriate alarm and or abort will activate if gas concentrations exceed the specified limits.

C. Describe tests or experiments which differ from those described in the AUTHORIZATION BASIS documentation?
N/A
NO $X$
Yes/Maybe

Basis: No the tests are not changed by the Referenced item implementations.

D. Is a change in a TSR, OSR, or compliance $\mathrm{plan}$ to OSR involved? $N / A$ NO $X$ Yes/Maybe

Basis:The Authorization basis establishes safe Mixer Pump operating limits for gas concentrations. The reference item ensures that the appropriate alarm and or abort will activate if gas concentrations exceed the specified limits.

USQE \#1 DC LARSEN

Print Name

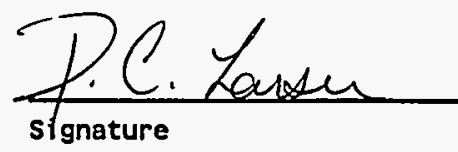

USQE \#2 MF ERHART

Print Name

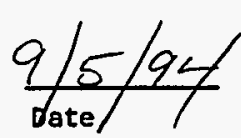

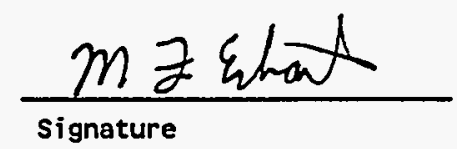




\section{RELEASE AUTHORIZATION}

Document Number: WHC-SD-WM-ATP-098, REV 0

Document Title: GMS/DACS INTERFACE ACCEPTANCE TEST PROCEDURE

Release Date: $\quad 9 / 22 / 94$

This document was reviewed following the procedures described in WHC-CM-3-4 and is:

APPROVED FOR PUBLIC RELEASE

*************** $* * *$

WHC Information Release Administration Specialist:

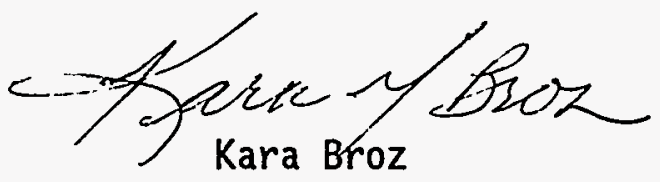

(Signature)
$9 / 22 / 94$

(Date) 


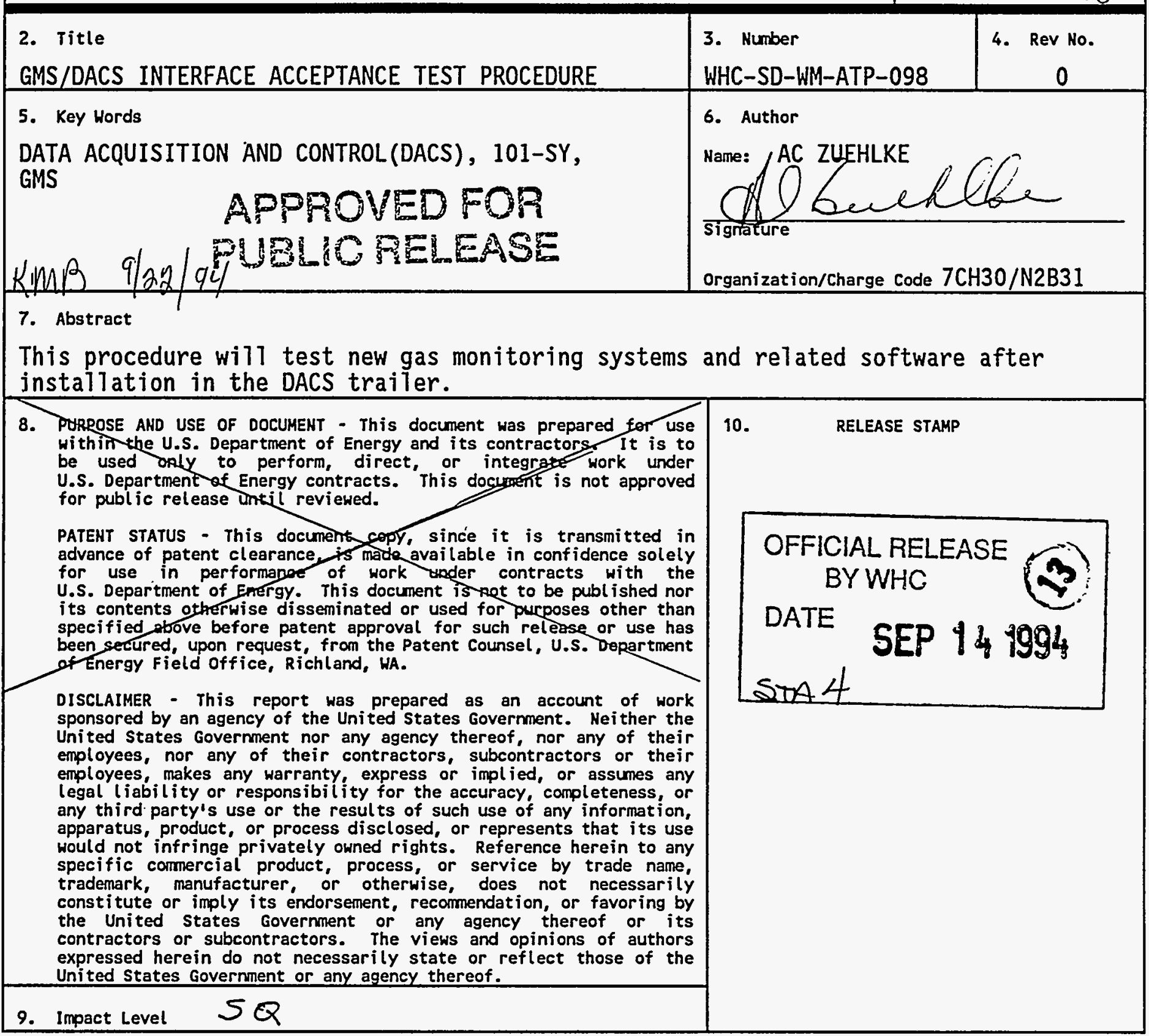

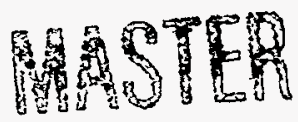




\title{
GMS/DACS INTERFACE ACCEPTANCE TEST PROCEDURE
}

\author{
WHC-SD-WM-ATP-098 \\ REVISION 0
}

SEPTEMBER 1994 


\section{TABLE OF CONTENTS}

1.0 PURPOSE $/ S C O P E \ldots \ldots \ldots \ldots$

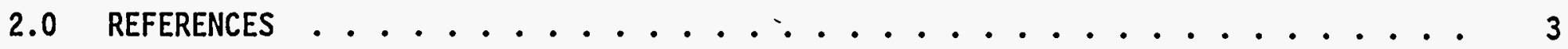

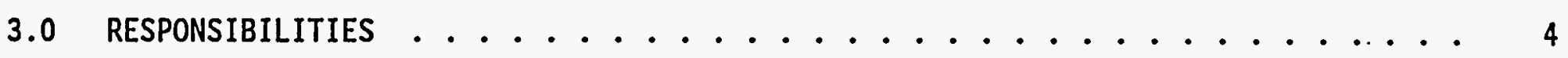

4.0 DESCRIPTION OF THE SYSTEM . . . . . . . . . . . . . . . . . . 5

5.0 TEST CONDITIONS AND EQUIPMENT REQUIRED . . . . . . . . . . . . . . 5

6.0 ACCEPTANCE TEST . . . . . . . . . . . . . . . . . . . . 7

6.1 Checks of Gas Analysis Equipment Readouts . . . . . . . . . . . . 7

6.2 Drop 13 I/0 Health Status Check .......................... 12

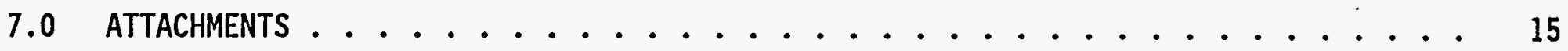

Attachment 1: Exception List .................. 16

Attachment 2: Final Procedure Acceptance Sheet ............... 17

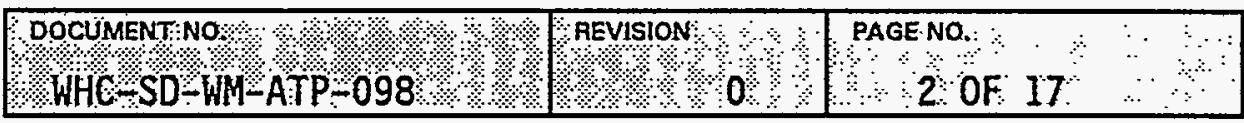




\subsection{PURPOSE/SCOPE}

The readiness of the Data Acquisition and Control System (DACS) to provide monitoring of existing, and newly installed, instrumentation associated with the SY-101 tank Gas Monitoring Systems will be systematically evaluated by performance of this procedure.

A11 new alarms will be verified to function at the required setpoints.

The change of I/O Drop 17 to I/O Drop 13 will be checked to verify that all associated alarms and screen displays are correct.

A11 new or changed Control Screens which provide operator interface with the Gas Monitoring Systems readouts during operations will be verified to be adequate and correct.

\subsection{REFERENCES}

2.1 LAUR-92-3196, "Safety Assessment for Proposed Pump Operation to Mitigate Episodic Gas Releases in Tank 241-SY-101"

2.2 WHC-CM-1-6, WHC Radiological Control Manual

2.3 HHC-CM-4-3, Industrial Safety Manual, Vols 1-3

2.4 WHC-CM-4-15, Radiation Work Requirements and Permits Manual, Vol 2

2.5 WHC-CM-4-40, Industrial Hygiene Manual

2.6 WHC-CM-6-1, Standard Engineering Practices, EP-5.8, "Engineering Document Contents"

2.7 WHC-CM-6-1, Appendix M, "Acceptance Test Procedures and Reports"

2.8 WHC-IP-0263-TF, Westinghouse Hanford Company Building Emergency PIan, Appendix G, "S-Farm Complex"

2.9 WHC-IP-0842, Waste Tank Project Administration, Section 5.9.1, "Lockout/Tagout"

2.10 WHC-IP-0842, Waste Tank Project Administration, Section 15.3

2.11 WHC-SD-WM-ATP-046, "SY-101 Mitigation Testing Acceptance Test Procedure", Rev 0

2.12 WHC-SD-WM-HSP-002, Tank Farm Health and Safety Plan

2.13 WHC-SD-WM-MA-014, "Mitigation Test Management"

2.14 WHC-SD-WM-TP-140, "Test P1an for Tank 101-SY Mitigation-By-Mixing Test"

\begin{tabular}{|c|c|}
\hline DOCUMENT NO: & 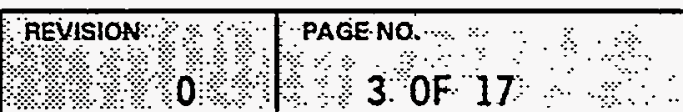 \\
\hline
\end{tabular}




\subsection{RESPONSIBILITIES}

The following personnel will be required for the performance of this procedure:

- Test Manager: The individual assigned direct responsibility for the performance, preparation, and adequacy of the test.

- Test Director: The engineer assigned shift responsibility for performance of the test.

- Test Engineer: The engineer assigned to assist and relieve the Test Director during the performance of the test.

- Gas Monitoring Systems Personnel: Personnel, familiar with the operation of the Gas Monitoring System equipment, assigned to assist with this test procedure.

Only personnel designated by the Mitigation Testing Program Test Manager are allowed to direct testing per this procedure, and perform operating and control functions using the DACS computer system.

One engineer acting as either a Test Engineer or as a Test Director is required to be present in the DACS trailer during testing.

If, during testing, any indicated parameter, control function, or screen display is not correct or appears to be malfunctioning, then the engineer conducting this test shall make a determination as to the feasibility of continuing testing. Since actual mixer pump motor operation will not occur during this test, there will be no safety impact to continuing the test and completing corrective actions later. A record of a11 noted deficiencies will be kept on Attachment 1, "Exception List".

At the completion of al1 testing, approval of all data collected and DACS system performance sha7l be documented on Attachment 2, "Final Procedure Acceptance Sheet".

A11 changes to this procedure shall be implemented by ECN, and shall receive the approval signatures appropriate to the approval designation of the change.

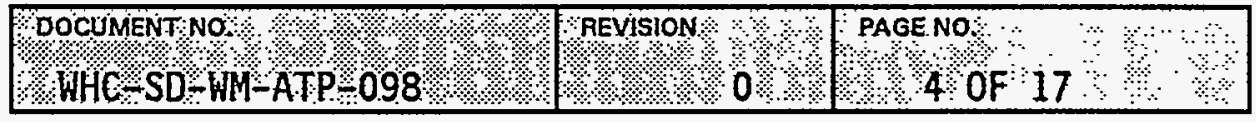




\subsection{DESCRIPTION OF THE SYSTEM}

The DACS, which is housed in a trailer located just outside of the north fence at the SY tank farm, receives input signals from a variety of sensors located in and around the SY-101 tank. These sensors provide information such as:

- Tank vapor space and ventilation system $\mathrm{H}_{2}$ concentration

- Tank waste temperature

- Tank pressure

- Waste density

- Operating pump parameters such as speed, flow, rotational position, discharge pressure, and internal temperature

- Strain (for major equipment)

- Waste level

The output of these sensors is conditioned and transmitted to the DACS computers where these signals are displayed, recorded, and monitored for out-of-specification conditions. If abnormal conditions are detected, then, in certain situations, the DACS automatically generates alarms and causes the system to abort pump operations.

The portions of the system to be tested include:

- New RGA5 gas monitor

- Existing gas chromatographs

- FTIR

- B \& K (PHOTO) $\mathrm{NH}_{3}$ equipment

- Any new or changed Genesis screens

- I/0 Drop 13

\subsection{TEST CONDITIONS AND EQUIPMENT REQUIRED}

5.1 The provisions of the following manuals apply to all work performed under this procedure:

- HHC-CM-1-6, WHC Radiological Control Manual

- WHC-CM-4-3, Industrial Safety Manual, Vols 1-3

- WHC-CM-4-15, Radiation Hork Requirements and Permits Manual, Vol 2

- WHC-CM-4-40, Industrial Hygiene Manual

- WHC-SD-WM-HSP-002, Tank Farm Health and Safety PTan

\subsection{Lock and Tag Control}

No locks and tags will be required for this procedure.

5.3 Jumpers and Lifted Leads

No leads will be 1 ifted or jumpers installed during performance of this procedure.

\begin{tabular}{|c|c|}
\hline OOCUMENT NO & 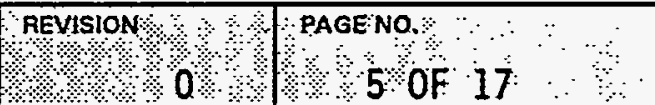 \\
\hline
\end{tabular}




\subsection{Unexpected A1 arms}

If unexpected, non-DACS, tank farm equipment al arms or abnormal indications are received during testing at the DACS trailer, then 101-SY testing evolutions shall be immediately suspended and actions, as prescribed in approved Tank Farms Alarm Response and Emergency Procedures, shall be taken by Tank Farms Operations personnel to place the equipment/farm in a safe, stable condition. When the reason for the unexpected condition is understood and resolved, then 101-SY testing activities may be resumed after permission to do so is received from the responsible West Area Shift Manager (WASM) and Test Manager.

5.5 Prior to initiation of testing at the DACS trailer or in the SY tank farm, and at the start of each Tank Farms Operations shift during testing, the Hest Area Shift Manager shall be briefed on the scope of testing to be conducted during the shift. The briefing shall include a request to verify that the mixer pump motor local disconnect switch, DS-101-25, and the rotation motor local disconnect switch, DS-101-26, are locked and tagged OFF, if required to support testing activities. Additionally, a discussion of work in the tank farm that could affect testing shall also be held between the West Area Shift Manager and the acting Test Director in charge of the test to be conducted.

5.6 Prior to initiation of testing, the following items shall be verified:

5.6.1 A11 software changes related to the Gas Monitoring Systems have been verified to be installed and ready for testing at the DACS trailer.

Verified by:

(Test Director) Date

5.6.2 For each test section, as determined by the West Area Shift Manager, a pre-job safety meeting, including a review of any applicable JHA, shall be conducted in accordance with a Pre-Job Safety Meeting Form, per WHC-IP-0842, Waste Tank Project Administration, Section 15.3.

5.6.3 The DACS computer at Station \#5 shall be available to support testing activities per this procedure.

5.7 Prior to initiation of testing, the following equipment shall be available for use:

5.7.1 Stopwatch, with commercial accuracy (no calibration required)

GOCUMENT:NO




\subsection{ACCEPTANCE TEST}

\subsection{Checks of Gas Analys is Equipment Readouts}

6.1.1 If any discrepancy is noted during testing, then record a description of the condition in Attachment 1.

6.1.1.1 For each discrepancy recorded, enter an identifying number in the "EXCEPTION NUMBER" Column of Attachment 1.

6.1.1.2 Reproduce Attachment 1 as needed, and attach the additional pages to this procedure, to record all discrepancies noted during testing.

NOTE: Testing per this section will require close coordination of the Test Director and Gas Monitoring Systems personnel.

6.1.2 Request Gas Monitoring Systems personnel to monitor the Gas Analysis Systems computer in Rack 10/CB A-5, in the rear of the DACS trailer for incoming data.

6.1.3 At Station \#5, access the GASSUM screen.

6.1.4 Request Gas Monitoring Systems Personnel to call out what the GC-1 $\mathrm{H}_{2}$ reading at Station \#5 should be at the next update, based on the indications displayed at the Gas Analysis computer.

6.1.4.1 Record the reading called out in Step 6.1.4:

(1)

6.1 .5
(2)

(3)

When the GC- $1 \mathrm{H}_{2}$ reading at Station \#5 updates, record the displayed value:

(1)

6.1 .6

6.1 .7

6.1 .8 same. Step 6.1.8.
(2)

(3)

Verify that the readings recorded in Steps 6.1.4.1 and 6.1.5 are the

Repeat Steps 6.1.4 through 6.1.6 two additional times, then goto

Request Gas Monitoring Systems Personnel to manually adjust the next $\mathrm{GC}-1 \mathrm{H}_{2}$ input to Station $\# 5$ to $15 \mathrm{ppm}$.

\begin{tabular}{|c|c|c|}
\hline $\begin{array}{l}\text { DOCUMENT:NO } \\
\text { HHC }=S D=W M=A T P=098\end{array}$ & REYISION & $\begin{array}{l}\text { PAGENO } \\
\text { T OF } 17\end{array}$ \\
\hline
\end{tabular}


6.1.9 When the $\mathrm{GC}-1 \mathrm{H}_{2}$ reading at Station \#5 updates, then verify that the displayed value is $15 \mathrm{ppm}$ and that a low hydrogen concentration alarm has been received on the MANABRT and ALARM/EVENT SUMMARY screens.

6.1.10 Request Gas Monitoring Systems Personnel to manually adjust the next $\mathrm{GC}-1 \mathrm{H}_{2}$ input to Station \#5 to $0 \mathrm{ppm}$.

6.1.11 When the GC-1 $\mathrm{H}_{2}$ reading at Station \#5 updates, then verify that the displayed value is $0 \mathrm{ppm}$ and that either a GC1-INST or GC1-ZVAL alarm or both has (have) been received on the ALARM/EVENT SUMMARY screen.

6.1.12 Request Gas Monitoring Systems Personnel to manually adjust the next $\mathrm{GC}-1 \mathrm{H}_{2}$ input to Station \#5 to a value greater than $15 \mathrm{ppm}$.

6.1.13 When the $\mathrm{GC}-1 \mathrm{H}_{2}$ reading at Station \#5 updates, then verify that the displayed value is greater than $15 \mathrm{ppm}$ and that no GC-1 alarms are active on the MANABRT and ALARM/EVENT SUMMARY screens.

6.1.14 Request Gas Monitoring Systems Personnel to manually stop the GC-1 $\mathrm{H}_{2}$ input to Station $\# 5$.

6.1.15 When Gas Monitoring Systems Personnel state that the $\mathrm{GC}-1 \mathrm{H}_{2}$ input to Station \#5 has been manually stopped, then start a stopwatch.

6.1.16 When the GCI-INST alarm is received at Station \#5, then stop the stopwatch and record the elapsed time: mins/secs.

6.1.16.1 Verify that the time recorded in Step 6.1.16 is approximately 7 mins 30 seconds.

6.1.17 Request Gas Monitoring Systems Personnel to manually restart the $\mathrm{GC}-1 \mathrm{H}_{2}$ input to Station \#5.

6.1.18 Request Gas Monitoring Systems Personnel to call out what the GC-2 $\mathrm{H}_{2}$ reading at Station $\# 5$ should be at the next update, based on the indications displayed at the Gas Analysis computer.

6.1.18.1 Record the reading called out in Step 6.1.18:

(1)

6.1 .19

When the $\mathrm{GC}-2 \mathrm{H}_{2}$ reading at Station \#5 updates, record the displayed value:

(1)

6.1.20 Verify that the readings recorded in Steps 6.1.18.1 and 6.1.19 are the same. 
6.1.21 Repeat Steps 6.1.18 through 6.1.20 two additional times, then goto Step 6.1.22.

6.1.22 Request Gas Monitoring Systems Personnel to call out what the GC-3 $\mathrm{H}_{2}$ reading at Station $\# 5$ should be at the next update, based on the indications displayed at the Gas Analysis computer.

6.1.22.1 Record the reading called out in Step 6.1.22:

(1)

6.1 .23

When the $\mathrm{GC}-3 \mathrm{H}_{2}$ reading at Station \#5 updates, record the displayed value:

(1)

6.1 .24

6.1 .25

6.1 .26 the same. Step 6.1.26.

6.1.26.1 Record the reading called out in Step 6.1.26:

(2)

(2)

(3)

(3)

Verify that the readings recorded in Steps 6.1 .22 .1 and 6.1 .23 are

Repeat Steps 6.1.22 through 6.1.24 two additional times, then goto

Request Gas Monitoring Systems Personnel to call out what the FTIR $\mathrm{NH}_{3}$ reading at Station $\# 5$ should be at the next update, based on the indications displayed at the Gas Analysis computer.

(2)

(3)

6.1.27 When the FTIR $\mathrm{NH}_{3}$ reading at Station \#5 updates, record the displayed value:

(1)

(2)

(3)

6.1.28 Verify that the readings recorded in Steps 6.1.26.1 and 6.1.27 are the same.

6.1.29 Repeat Steps 6.1.26 through 6.1.28 two additional times, then goto Step 6.1.30.

6.1.30 Request Gas Monitoring Systems Personnel to manual1y adjust the next FTIR $\mathrm{NH}_{3}$ input to Station \#5 to $3000 \mathrm{ppm}$.

6.1.31 When the FTIR $\mathrm{NH}_{3}$ reading at Station \#5 updates, then verify that the displayed value is $3000 \mathrm{ppm}$ and that a FTIR NH3 CONCENTRATION al arm has been received on the ALARM/EVENT SUMMARY screen.

6.1.32 Request Gas Monitoring Systems Personnel to return the FTIR $\mathrm{NH}_{3}$ input to Station \#5 to normal.

\%


6.1.33 Request Gas Monitoring Systems Personnel to call out what the FTIR $\mathrm{NO}_{2}$ reading at Station $\# 5$ should be at the next update, based on the indications displayed at the Gas Analysis computer.

6.1.33.1 Record the reading called out in Step 6.1.33:

(1)

6.1 .34
(2)

(3)

When the FTIR $\mathrm{NO}_{2}$ reading at Station \#5 updates, record the displayed value:

(1)

6.1 .35

6.1 .36

6.1 .37 the same. Step 6.1.37.
(2)

(3)

Verify that the readings recorded in Steps 6.1.33.1 and 6.1.34 are

Repeat Steps 6.1 .33 through 6.1 .35 two additional times, then goto

Request Gas Monitoring Systems Personnel to call out what the B \& K (PHOTO) $\mathrm{NH}_{3}$ reading at Station $\# 5$ should be at the next update, based on the indications displayed at the Gas Analys is computer.

6.1.37.1 Record the reading called out in Step 6.1.37:

(1)

(2)

(3)

6.1 .38

When the $B \& \mathrm{~K}$ (PHOTO) $\mathrm{NH}_{3}$ reading at Station $\# 5$ updates, record the displayed value:

(1)

6.1 .39

6.1 .40

6.1 .41

6.1 .42

6.1 .43 the same. Step 6.1.41. screen.
(2)

(3)

Verify that the readings recorded in Steps 6.1.37.1 and 6.1.38 are

Repeat Steps 6.1.37 through 6.1.39 two additional times, then goto

Request Gas Monitoring Systems Personnel to manually adjust the next B \& K (PHOTO) $\mathrm{NH}_{3}$ input to Station \#5 to $1000 \mathrm{ppm}$.

When the $B$ \& $\mathrm{K}$ (PHOTO) $\mathrm{NH}_{3}$ reading at Station \#5 updates, then verify that the displayed value is $1000 \mathrm{ppm}$ and that a STACK NH3 CONCENTRATION alarm has been received on the ALARM/EVENT SUMMARY

Request Gas Monitoring Systems Personnel to manually adjust the next B \& $\mathrm{K}$ (PHOTO) $\mathrm{NH}_{3}$ input to Station \#5 to $0 \mathrm{ppm}$.

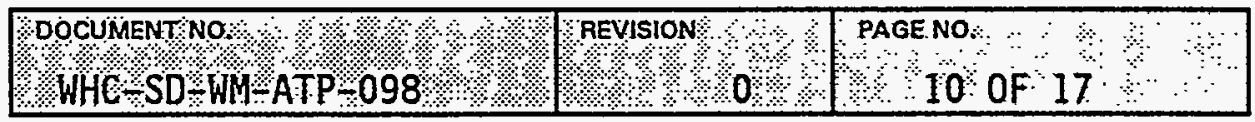


6.1.44 When the $\mathrm{B} \& \mathrm{~K}$ (РHOTO) $\mathrm{NH}_{3}$ reading at Station \#5 updates, then verify that the displayed value is $0 \mathrm{ppm}$ and that a NH3-INST alarm has been received on the ALARM/EVENT SUMMARY screen.

6.1.45 Request Gas Monitoring Systems Personnel to return the B \& K (PHOTO) $\mathrm{NH}_{3}$ input to Station $\# 5$ to normal.

Testing as directed by this procedure section has been completed, and discrepancies, if any, have been 1isted on Attachment 1, Exception List.

Test Engineer: Date: 


\subsection{Drop 13 I/0 Health Status Check}

6.2.1 If any discrepancy is noted during testing, then record a description of the condition in Attachment 1 .

6.2.1.1 For each discrepancy recorded, enter an identifying number in the "EXCEPTION NUMBER" Column of Attachment 1 .

6.2.1.2 Reproduce Attachment 1 as needed, and attach the additional pages to this procedure, to record all discrepancies noted during testing.

6.2.2 At Station \#5, access the "ALARM/EVENT SUMMARY" screen.

6.2.3 At Station \#6, access the "I/O HEALTH STATUS" screen.

6.2.4 Verify that the indicated status for the following is "OK", in GREEN Tetters:

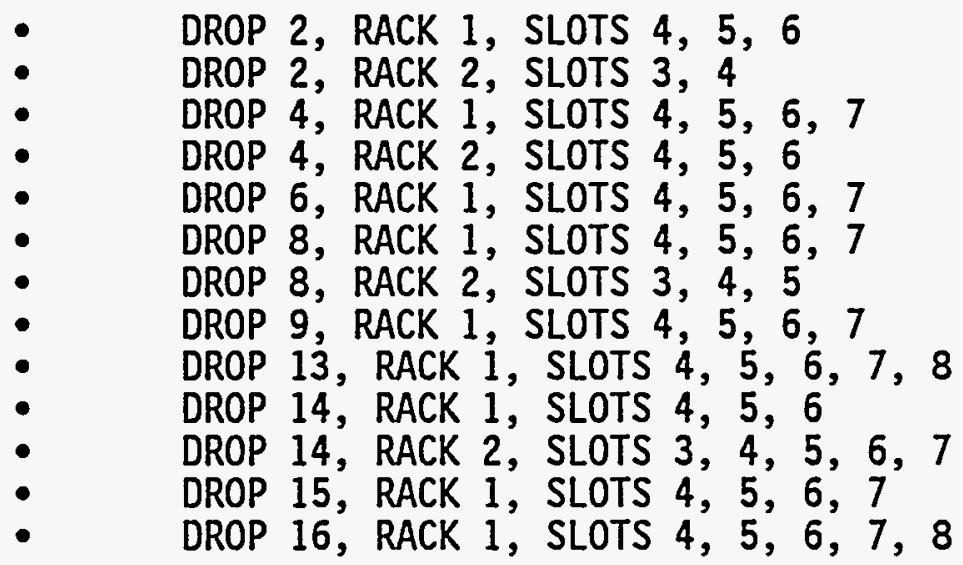

6.2.5 Refer to Table IP for information related to the modules to be tested in Drop 13.

6.2.6 For each instrument listed in Table IP:

6.2.6.1 Direct field personnel to:

6.2.6.1.1 Locate the rack for the module to be tested.

6.2.6.1:2 Locate the module to be tested.

6.2.6.1.3 Turn off power for the rack.

6.2.6.1.4 Remove the module to be tested from the rack.

6.2.6.1.5 Restore power to the rack.

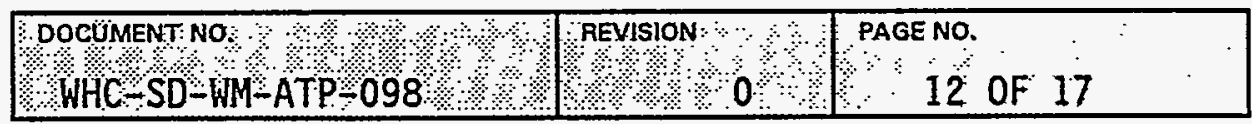


6.2.6.2 Verify that the alarm associated with the module that was removed from the rack, as listed in the "ALARM" column of Table IP, is received at Station \#5.

6.2.6.3

Acknowledge the alarm at Station \#5.

6.2 .6 .4

Verify, after a time delay, that the indicated status at Station \#6 for the module being tested, changes from "OK" in GREEN letters to "BAD" in RED letters, and initial the "OK TO BAD" column in Table IP.

$6.2 \cdot 6.5$

Direct field personnel to:

6.2.6.5.1 Turn off power to the rack.

6.2.6.5.2 Reinstall the module being tested into the rack, and remove the next module to be tested from the rack.

6.2.6.5.3 Restore power to the rack.

6.2.6.6 Verify, after a time delay, that the indicated status at

Station \#6, for the module that was replaced, changes from "BAD" in RED letters to "OK" in GREEN letters, and initial the "BAD TO OK" column in Table IP.

6.2.6.7 Verify that the alarm at Station \#5, for the module that was replaced, is clear.

6.2.6.8 Enter "YES" or "NO" in the "Test Sat ?" column.

6.2.6.8.1 If a "NO" was entered in the "Test Sat ?" column, then 1 ist the discrepancy on Attachment 1.

6.2 .6 .9

Repeat Steps 6.2.6.1 through 6.2.6.8.1 until testing for all modules in Drop 13 is complete.

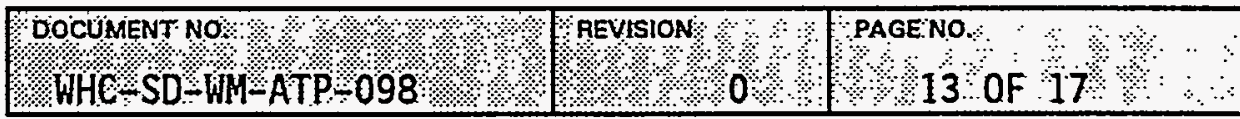


Table IP

\begin{tabular}{|c|c|c|c|c|}
\hline MODULE & ALARM & $\begin{array}{l}\text { "OK" TO } \\
\text { "BAD" }\end{array}$ & $\begin{array}{c}\text { "BAD" TO } \\
\text { "OK" }\end{array}$ & $\begin{array}{c}\text { Test Sat ? } \\
(\mathrm{YES} / \mathrm{NO})\end{array}$ \\
\hline $\begin{array}{l}\text { DROP } 13, \\
\text { RACK } 1 \text {, SLOT } \\
4\end{array}$ & $\begin{array}{c}\text { J11C12 D013 DROP 13 RACK } \\
1 \text { I } / 0 \text { HEALTH }\end{array}$ & & & \\
\hline $\begin{aligned} & \text { DROP } 13, \\
& \text { RACK } 1, \text { SLOT } \\
& 5 \\
&\end{aligned}$ & $\begin{array}{c}\text { J11C12 D012 DROP 13 RACK } \\
1 \text { I } / 0 \text { HEALTH }\end{array}$ & & & \\
\hline $\begin{array}{l}\text { DROP } 13, \\
\text { RACK } 1, \text { SLOT } \\
6\end{array}$ & $\begin{array}{c}\text { J11C12 D011 DROP 13 RACK } \\
1 \text { I } / 0 \text { HEALTH }\end{array}$ & & & \\
\hline $\begin{array}{l}\text { DROP } 13, \\
\text { RACK } 1, \text { SLOT } \\
7\end{array}$ & $\begin{array}{c}\text { J11C12 D010 DROP 13 RACK } \\
1 \text { I } / 0 \text { HEALTH }\end{array}$ & & & \\
\hline $\begin{array}{l}\text { DROP } 13, \\
\text { RACK } 1, \text { SLOT } \\
8\end{array}$ & $\begin{array}{c}\text { J11C12 D09 DROP 13 RACK } \\
1 \text { I/0 HEALTH }\end{array}$ & & & \\
\hline
\end{tabular}

Testing as directed by this procedure section has been completed, and discrepancies, if any, have been 7 isted on Attachment 1, Exception List.

Test Engineer: Date: 


\subsection{ATTACHMENTS}

Attachment 1, Exception List

Attachment 2, Final Procedure Acceptance Sheet. 


\section{GMSIDACS INTERFACE ACCEPTANCE TEST PROCEDURE}

\begin{tabular}{|c|c|c|c|c|c|}
\hline $\begin{array}{c}\text { EXCEPTION } \\
\text { NUMBER }\end{array}$ & $\begin{array}{c}\text { STEP } \\
\text { NUMBER }\end{array}$ & EXCEPTION DESCRIPTION & EXCEPTION RESOLUTION & $\begin{array}{l}\text { RESOLUTION } \\
\text { APPROVED BY: }\end{array}$ & $\begin{array}{c}\text { DATE } \\
\text { RESOLVED }\end{array}$ \\
\hline & & & & & \\
\hline & & & & & \\
\hline & & & & & \\
\hline & & & & & \\
\hline & & & & & \\
\hline & & & & & \\
\hline & & & & & \\
\hline & & & & & \\
\hline & & & & & \\
\hline & & & & & \\
\hline & & & & & \\
\hline & & & & & \\
\hline
\end{tabular}

Attachment 1: Exception List

\begin{tabular}{|c|c|c|}
\hline $\begin{array}{l}\text { DOCUMENT NO, } \\
\text { WHC-SD-WM-ATP-098 }\end{array}$ & REVISION & PAGE NO \\
\hline
\end{tabular}


Completion of this procedure has demonstrated that:

- The Gas Monitoring Systems signals to DACS are being processed and displayed correctly at the DACS screens.

- A11 new alarms have been verified to actuate at the correct setpoints.

- Al1 new or changed screens have been tested for proper display of Gas Monitor System parameters.

- The alarms and screens associated with I/O Drop 13 have been tested to functi correctly.

- A record of all noted deficiencies was kept on Attachment 1, Exception List, and al1 recorded exceptions have been resolved and the resolutions approved.

Approved by:

\begin{tabular}{|c|c|}
\hline D. C. Larsen, Test Manager & Date \\
\hline R. W. Reed, Test Engineering & Date \\
\hline
\end{tabular}

Attachment 2: Final Procedure Acceptance Sheet

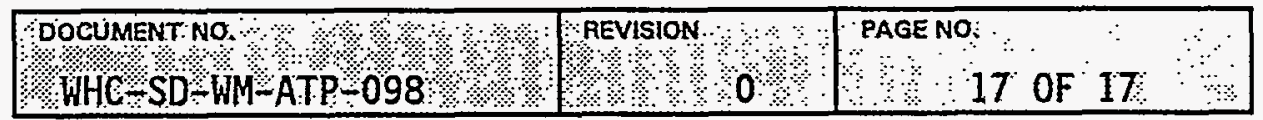

